\title{
Genetic diversity of lactic acid bacteria isolated from Sumbawa horse milk, Indonesia
}

\author{
KUSDIANAWATI $^{1, \boldsymbol{v}}$, APON Z. MUSTOPA ${ }^{2}$, FATIMAH ${ }^{3}$, BUGI R. BUDIARTO ${ }^{2}$ \\ ${ }^{1}$ Department of Biotechnology, Faculty of Biotechnology, Universitas Teknologi Sumbawa. Jl. Raya Olat Maras, Moyo Hulu, Sumbawa 84371, \\ West Nusa Tenggara, Indonesia. Tel./fax.: +62-371-2629009, ^email: kusdianawatibtk@gmail.com \\ ${ }^{2}$ Research Center for Biotechnology, Indonesian Institute of Sciences. Jl. Raya Bogor Km. 46, Cibinong, Bogor 16911, West Java, Indonesia \\ ${ }^{3}$ Indonesian Center for Agricultural Biotechnology and Genetic Resources Research and Development. Jl. Tentara Pelajar No. 3A, Cimanggu, Bogor \\ 16111, West Java, Indonesia
}

Manuscript received: 13 May 2020. Revision accepted: 22 June 2020.

\begin{abstract}
Kusdianawati, Mustopa AZ, Fatimah, Budiarto BR. 2020. Genetic diversity of lactic acid bacteria isolated from Sumbawa horse milk, Indonesia. Biodiversitas 21: 3225-3233. LAB from Sumbawa horse milk has good potential antimicrobial and probiotic agents. It is known, the study on LAB diversity based on its phenotypic characters is difficult to be distinguished. However, the development of molecular characterization based on the genotypic characteristic could be done for LAB diversity analysis. The aim of this study is to obtain the genetic diversity of LAB from Sumbawa horse milk collected from Penyaring Village and Lennanguar Village, Sumbawa, West Nusa Tenggara Indonesia. LAB strains were identified based on their genotypic characteristics, including their randomly amplified polymorphic DNA (RAPD) primers profiles and 16S ribosomal RNA (rRNA) sequences. The result of RAPD-PCR analysis showed 5 clusters of dendrograms resulted from GTG5 and LB2 primer amplification. Based on 16 rRNA sequences result, the phylogenetic tree was constructed and revealed 7 species of LAB i.e: SK 1.5, SKP K.3, SKP K.5, SKP K.9/SKP K.7/M.SKP K.3, SKL K.4, M.SKL K.1/ M.SKL K.5, and SKP K.4 belonging to the species of Enterococcus faecium, Weissella confusa, Lactococcus garvieae, Enterococcus thailandicus, Lactobacillus fermentum, Enterococcus faecalis, and Lactococcus petauri. In this study, the bacteria from Enterococcus sp., Lactococcus garvieae, and Lactococcus petauri existed as a novel of bacteria which means they have not been isolated and identified in Sumbawa horse milk compared to the previous findings.
\end{abstract}

Keywords: 16S rRNA analysis, LAB, RAPD-PCR analysis, Sumbawa horse milk

\section{INTRODUCTION}

Sumbawa is one of the districts in Nusa Tenggara Barat (NTB). Sumbawa horse milk is a local food product in Sumbawa, which has unique characteristics. The milk is not clumped when heated and acidic due to the presence of lactic acid bacteria (LAB) (Hermawati et al. 2004). The results extraction of active compounds from Sumbawa horse milk produced an organic compound as protein (galactoequin or galactoferrin) that has strong antimicrobial activity with bacteria pathogen (Hermawati 2005). Also, Sumbawa horse milk has a LAB that can ferment milk into acids and produce antimicrobial compounds such as bacteriocin, lactic acid, organic acids (acetate and hydrogen peroxide) (Hakim et al. 2013; Manguntungi et al. 2018; Sujaya et al. 2008; Zacharof and Lovitt 2012). LAB isolated from Sumbawa horse milk has antimicrobial activity to Staphlococcus aureus, Escherichia coli, Salmonella thypimurium, and Shigella flexneri (Suyaja et al. 2008)

Sumbawa horse milk contains the highest lactose $(6.2 \mathrm{~g}$ / $100 \mathrm{~g}$ ) compared to other dairy milk. The high lactose content is produced by horse milk fermentation $(\mathrm{pH} 3.1)$ from the excessive organic acids of LAB (Sujaya et al. 2008). Some of LAB bacteria species contained in Sumbawa horse milk consist of Lactobacillus brevis, Lactobacillus plantarum, Lactobacillus acidophilus, Lactobacillus salivarius, Lactobacillus delbrueckii subsp. delbrueckii and Lactococcus lactis subsp. Lactic, Lactobacillus bulgaricus, Lactobacillus rhamnosus, Streptococcus lactis, Tarula sp., Weissella sp., Leuconostoc sp., or Ochrobactrum oryza and others LAB group which have not been identified (Mulyawati 2019; Sujaya et al. 2008; Widiada 2006). Yeasts group are also existed causing low pH of milk ranged in 3.1 (Sujaya et al. 2008). However, until now, there is still less of research addressing the genetic diversity of LAB found in Sumbawa horse milk. In the previous study, the LAB from Sumbawa horse milk has good potential antimicrobial and probiotic agents (Shi et al. 2012; Sujaya et al. 2008). It is known, the study on LAB diversity based on its phenotypic characters (morphological, biochemical, and physiological characters) is difficult to be distinguished. However, the development of molecular characterization based on the genotypic characteristic could be done for LAB diversity analysis. The results of this study expected to provide information on polymorphism patterns and obtained a phylogenetic tree from Sumbawa horse milk.

The genetic diversity of LAB is seen from amplification LB2 (Ben Omar 2000) and GTG5 primer (Gevers et al. 2001) on the LAB genomic DNA using Random amplified polymorphic DNA (RAPD). RAPD is a molecular technique to apply certain markers to study genetic diversity. RAPD is a useful approach to assessing genetic variation for the conservation of wild microorganisms; It is 
based on PCR amplification of genomic DNA with arbitrary nucleotide sequence primers. The RAPD marker can detect high levels of DNA polymorphism and can produce fine genetic markers (Welsh and McClelland 1990; Williams et al. 1990). The analysis of RAPD result can be computerized that allow rapid identification of the unknown isolates. Therefore, there are several recent studies conducted on identifying genetic diversity of LAB using RAPD method (Chao et al. 2008; Chao et al. 2012; Delavenne et al. 2012; Mustopa and Fatimah 2014). This study aims to obtain LAB genetic diversity based on their genotypic characteristics through isolation, molecular marker screening using RAPD primers, and identify $16 \mathrm{~S}$ rRNA sequences in Sumbawa horse milk.

\section{MATERIALS AND METHODS}

\section{Study area}

Samples were collected at horse farms in Penyaring Village and Lennanguar Village, Sumbawa, West Nusa Tenggara (NTB), Indonesia. The time to take a Sumbawa horse milk sample from two different villages were done on the same day. Condition of milk samples obtained from horses in fresh and good condition. Milk was stored at $4{ }^{\circ} \mathrm{C}$ using iceboxes to keep milk safe in good condition until observation in the laboratory. The volume of the collected fresh milk was $500 \mathrm{~mL}$. The research was conducted from May to August 2019 in the Laboratory for Applied Genetic Engineering and Protein Design, Research Center for Biotechnology, Indonesian Institute of Sciences and Molecular Biology Laboratory and Genetic Resources Research and Development. Bogor, West Java, Indonesia.

\section{Procedures}

Isolation and identification of Lactic Acid Bacteria

LAB isolation method has been modified from Mustopa (2013). The LAB isolation of Sumbawa horse milk was carried out using a serial dilution method $\left(10^{-6}\right)$ using $0.85 \% \mathrm{NaCl}$. Aliquot of $100 \mu \mathrm{L}$ Sumbawa horse milk resulting from multilevel dilution $\left(10^{-6}\right)$ is, then, spread into the solid medium of de Mann Rogosa Sharp (MRS) and M17. The LAB isolates grown in MRS media were incubated at $28{ }^{\circ} \mathrm{C}$ and $37^{\circ} \mathrm{C}$ for 24 hours, while the isolates of LAB grown in M17 media were incubated at 30 ${ }^{\circ} \mathrm{C}$ for 24 hours. A single bacterial colony produced from the isolates then grown in $5 \mathrm{ml}$ of MRS and M17 liquid media.

Identification of genetic diversity LAB bacteria was conducted by isolation of LAB genomic DNA, PCRRAPD, and PCR 16S rRNA as follows:

\section{Isolation of genomic DNA}

LAB genomic DNA isolation has been modified from Mustopa and Fatimah (2014) method. LAB colonies were cultured in $5 \mathrm{~mL} \mathrm{MRS} \mathrm{(at} 28^{\circ} \mathrm{C}$ and $37{ }^{\circ} \mathrm{C}$ for 24 hours) and M17 (at $30{ }^{\circ} \mathrm{C}$ for 24 hours) media. Cell harvesting was performed by centrifugation at $11000 \mathrm{x} \mathrm{g}$ for 10 minutes. The pellet was resuspended with TE buffer (10 mM Tris- $\mathrm{HCl} \mathrm{pH} 8,1 \mathrm{mM}$ EDTA), $40 \mu \mathrm{L}$ of lysozyme (60 $\mathrm{mg} / \mathrm{mL}$ ) at $37{ }^{\circ} \mathrm{C}$ for $60 \mathrm{~min}$. The solution was added with isolation buffer $(200 \mu \mathrm{L}$ SDS $10 \%, 100 \mu \mathrm{L} \mathrm{NaCl} 5 \mathrm{M}, 80$ $\mu \mathrm{L} 10 \% \mathrm{CTAB}$ ) and incubated at $68^{\circ} \mathrm{C}$ for 30 minutes. Then, chloroform was added 1:1 (v/v), and centrifuged at $23000 \mathrm{x} \mathrm{g}$ for 10 minutes. The top phase solution was transferred to a new microtube, then isopropanol was added with a volume ratio of $1: 1$ and centrifuged. The DNA pellets were added by $1 \mathrm{~mL} 70 \%$ cold ethanol and inverted. Then, centrifuged at $10000 \mathrm{xg}$ for 2 minutes at $4^{\circ} \mathrm{C}$. The DNA pellets were aired overnight. Dried DNA was solubilized in $27 \mu \mathrm{L}$ of sterile water $\left(\mathrm{ddH}_{2} \mathrm{O}\right)$ and $3 \mu \mathrm{L}$ RNAse. The DNA solution incubated at $37^{\circ} \mathrm{C}$ for 30 minutes, then stored at $4^{\circ} \mathrm{C}$.

\section{RAPD-PCR}

RAPD-PCR was performed using methods and amplification conditions as described by Chao et al (2008). The primers used were LB2 (5'-GGTGACGC-3 ') (Ben Omar 2000) and GTG5 (5'-GTGGTGGTGGTGGTG-3') (Gevers et al. 2001). The solutions used in the PCR mix were $\mathrm{ddH}_{2} \mathrm{O} 3 \mu \mathrm{L}$, MyTaq master mix (Bioline) $7.5 \mu \mathrm{L}$, primers $1.5 \mu \mathrm{L}$, DNA template $3 \mu \mathrm{L}$ with total volume was $15 \mu \mathrm{L}$.

Single primer was used in two different PCR conditions. The LB2 primer was used in the first PCR condition, which consists of 1 cycle of $94{ }^{\circ} \mathrm{C}$ for $2 \mathrm{~min} ; 6$ cycles of $94{ }^{\circ} \mathrm{C}$ for $30 \mathrm{~s}, 36{ }^{\circ} \mathrm{C}$ for $1 \mathrm{~min}$, and $72{ }^{\circ} \mathrm{C}$ for 90 s; 30 cycles of $94{ }^{\circ} \mathrm{C}$ for $20 \mathrm{~s}, 36{ }^{\circ} \mathrm{C}$ for $30 \mathrm{~s}$, and $72{ }^{\circ} \mathrm{C}$ for $90 \mathrm{~s}$; and finally 1 cycle of $72{ }^{\circ} \mathrm{C}$ for $3 \mathrm{~min}$. The GTG5 primer was used in the second PCR condition, which consists of 1 cycle of $95^{\circ} \mathrm{C}$ for $7 \mathrm{~min} ; 30$ cycles of $95^{\circ} \mathrm{C}$ for $1 \mathrm{~min}, 55^{\circ} \mathrm{C}$ for $1 \mathrm{~min}$, and $65^{\circ} \mathrm{C}$ for $8 \mathrm{~min}$; and finally 1 cycle of $65^{\circ} \mathrm{C}$ for $16 \mathrm{~min}$. PCR products were separated on $2 \%(w / v)$ agarose gel electrophoresis using 1x TAE buffer. The gels were stained in ethidium bromide solution and photographed under UV transilluminator.

The result of the amplification band profile obtained from RAPD-PCR was analyzed using NTSYS 2.02 in the form of binary data ( 0 and 1$)$ to obtain a cluster analysis and produce dendrogram. The polymorphic information content (PIC) was computed as :

$$
\mathrm{PIC}_{\mathrm{i}}=2 \mathrm{f}_{\mathrm{i}}\left(1-\mathrm{f}_{\mathrm{i}}\right)
$$

Where $\mathrm{PIC}_{\mathrm{i}}$ is the polymorphic information content ' $i$ ', $\mathrm{f}_{\mathrm{i}}$ is the frequency of the amplified allele (band present), and $\left(1-f_{i}\right)$ is the frequency of the null allele (band absent) (Roldán-Ruiz et al. 2000; Soengas et al. 2006).

\section{PCR amplification for $16 S$ rRNA}

Primary sequences of $16 \mathrm{~S}$ rRNA primer $8 \mathrm{~F}$ (5'AGAGTTTGATCATGGCTCAG-3') and 16R (5'AAGGAGGTGATCCAACCGCA-3') (Chao et al. 2008). The solutions used in the PCR mix were $\mathrm{ddH}_{2} \mathrm{O} 38.5 \mu \mathrm{L}, 5$ $\times$ MyTaq Green $7.5 \mu \mathrm{L}$, primers $8 \mathrm{~F} 1 \mu \mathrm{L}$, primers $16 \mathrm{R} 1$ $\mu \mathrm{L}$, DNA template $2 \mu \mathrm{L}$ with total volume was $50 \mu \mathrm{L}$. The PCR conditions were $96{ }^{\circ} \mathrm{C}$ for $5 \mathrm{~min} ; 35$ cycles consisting of $96{ }^{\circ} \mathrm{C}$ for $1 \mathrm{~min}, 55^{\circ} \mathrm{C}$ for $3 \mathrm{~min}$, and $72^{\circ} \mathrm{C}$ for $1 \mathrm{~min}$; and $72{ }^{\circ} \mathrm{C}$ for $7 \mathrm{~min}$. The PCR products were subjected to gel electrophoresis on $1 \%$ agarose gel, followed by ethidium bromide staining and photographed under UV transilluminator. 
Sequencing and phylogenetic relationships of the lactic acid bacteria

The DNA sequencing was performed in the 1st BASE, Singapore. Similarity analysis was performed by online Basic Local Alignment Search Tool (BLAST) analysis in NCBI. The phylogenetic tree was constructed by Treeview software.

\section{RESULTS AND DISCUSSION}

\section{Isolation of Lactic Acid Bacteria}

Sumbawa horse milk was obtained from two different locations, Penyaring Village (SKP) and Lenangguar Village (SKL), Sumbawa Regency, NTB. Based on the physical appearance of horse milk there were differences in color, the thickness of milk, and strong acid odor as illustrated in (Figure 1). Therefore, the result of organoleptic tests shown from Sumbawa horse milk was white, sour taste, distinctive odor and having $\mathrm{pH}$ with a range of 2.73-4.25 (Hermawati 2005). The sour taste of Sumbawa horse milk has been correlated with the number of LAB which depends on variations in storage time (Hakim et al. 2013).

The result of isolation LAB from Sumbawa horse milk has produced 41 single colonies (Table 1). Then their genetic diversity identified was elucidated using PCRRAPD and PCR 16S rRNA.

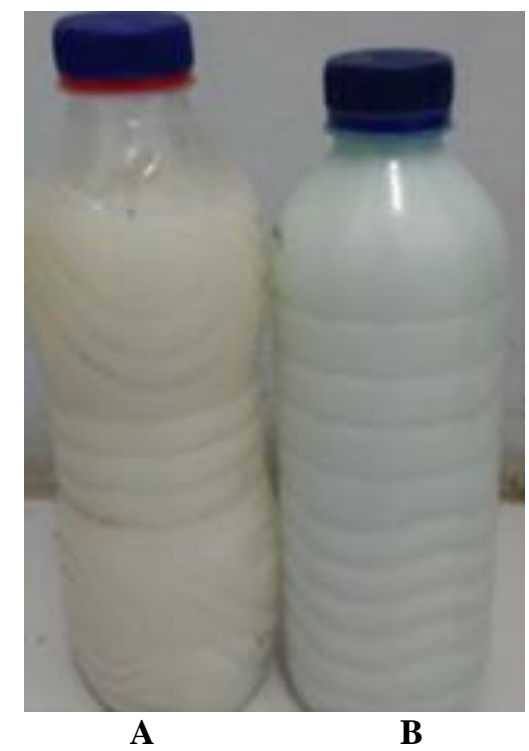

Figure 1. Sumbawa horse milk samples. A. Horse milk from Lenangguar Village (color: yellowish-white, thickness of milk: very thick, acidic odor: very stinging). B. Horse milk from Penyaring Village (color: white, thickness of milk: more dilute, smell acid: sting)

\section{Identification of Lactic Acid Bacteria $R A P D-P C R$}

Identification of LAB genetic diversity in this study used the RAPD-PCR method by applying primer GTG5 and LB2 (Mustopa and Fatimah 2014). As pointed in Figure 2, the RAPD-PCR profile showed various sizes of DNA amplification bands from each LAB specimen of two different horse milk sources. Interestingly, two different primers used in RAPD showed a different pattern of DNA bands where GTG5 primer (PIC 0,38) more likely gave variation in terms of $\mathrm{LAB}$ identified compared to LB2 primer (PIC 0,32). Furthermore, dendrogram analysis of LAB based on amplification bands of each isolate showed the diversity of LAB (Figures 3 and 4).

Table 1. LAB isolate from Sumbawa horse milk

\begin{tabular}{|c|c|c|c|}
\hline Isolate code & Medium & Temp. & Origin \\
\hline LAB 1.1 & MRS & $37^{\circ} \mathrm{C}$ & Penyaring Village \\
\hline LAB 1.2 & MRS & $37^{\circ} \mathrm{C}$ & Penyaring Village \\
\hline LAB 1.4 & MRS & $37^{\circ} \mathrm{C}$ & Penyaring Village \\
\hline LAB 1.5 & MRS & $37^{\circ} \mathrm{C}$ & Penyaring Village \\
\hline LAB 1.6 & MRS & $37^{\circ} \mathrm{C}$ & Penyaring Village \\
\hline LAB 1.7 & MRS & $37^{\circ} \mathrm{C}$ & Penyaring Village \\
\hline LAB 1.8 & MRS & $37^{\circ} \mathrm{C}$ & Penyaring Village \\
\hline LAB SK 1.5 & MRS & $37^{\circ} \mathrm{C}$ & Penyaring Village \\
\hline LAB SK 2.1 & MRS & $37^{\circ} \mathrm{C}$ & Penyaring Village \\
\hline LAB SK 2.3 & MRS & $37^{\circ} \mathrm{C}$ & Penyaring Village \\
\hline SKP K.1 & MRS & $37^{\circ} \mathrm{C}$ & Penyaring Village \\
\hline SKP K.2 & MRS & $37^{\circ} \mathrm{C}$ & Penyaring Village \\
\hline SKP K.3 & MRS & $28{ }^{\circ} \mathrm{C}$ & Penyaring Village \\
\hline SKP K.4 & MRS & $28^{\circ} \mathrm{C}$ & Penyaring Village \\
\hline SKP K.5 & MRS & $28^{\circ} \mathrm{C}$ & Penyaring Village \\
\hline SKP K.6 & MRS & $28^{\circ} \mathrm{C}$ & Penyaring Village \\
\hline SKP K.7 & MRS & $28^{\circ} \mathrm{C}$ & Penyaring Village \\
\hline SKP K.8 & MRS & $37^{\circ} \mathrm{C}$ & Penyaring Village \\
\hline SKP K.9 & MRS & $37^{\circ} \mathrm{C}$ & Penyaring Village \\
\hline SKP K.10 & MRS & $37^{\circ} \mathrm{C}$ & Penyaring Village \\
\hline SKP K.11 & MRS & $37^{\circ} \mathrm{C}$ & Penyaring Village \\
\hline M.SKP K.1 & MRS & $37^{\circ} \mathrm{C}$ & Penyaring Village \\
\hline M.SKP K.2 & M17 & $30^{\circ} \mathrm{C}$ & Penyaring Village \\
\hline M.SKP K.3 & M17 & $30^{\circ} \mathrm{C}$ & Penyaring Village \\
\hline M.SKP K.4 & M17 & $30^{\circ} \mathrm{C}$ & Penyaring Village \\
\hline M.SKP K.5 & M17 & $30^{\circ} \mathrm{C}$ & Penyaring Village \\
\hline SKL K.1 & M17 & $30^{\circ} \mathrm{C}$ & Lenangguar Village \\
\hline SKL K.2 & MRS & $37^{\circ} \mathrm{C}$ & Lenangguar Village \\
\hline SKL K.3 & MRS & $37^{\circ} \mathrm{C}$ & Lenangguar Village \\
\hline SKL K.4 & MRS & $37^{\circ} \mathrm{C}$ & Lenangguar Village \\
\hline SKL K.5 & MRS & $37^{\circ} \mathrm{C}$ & Lenangguar Village \\
\hline SKL K.6 & MRS & $37^{\circ} \mathrm{C}$ & Lenangguar Village \\
\hline SKL K.7 & MRS & $28^{\circ} \mathrm{C}$ & Lenangguar Village \\
\hline SKL K.8 & MRS & $28^{\circ} \mathrm{C}$ & Lenangguar Village \\
\hline SKL K.9 & MRS & $28^{\circ} \mathrm{C}$ & Lenangguar Village \\
\hline SKL K.10 & MRS & $28^{\circ} \mathrm{C}$ & Lenangguar Village \\
\hline M.SKL K.1 & MRS & $28^{\circ} \mathrm{C}$ & Lenangguar Village \\
\hline M.SKL K.2 & M17 & $30^{\circ} \mathrm{C}$ & Lenangguar Village \\
\hline M.SKL K.3 & M17 & $30^{\circ} \mathrm{C}$ & Lenangguar Village \\
\hline M.SKL K.4 & M17 & $30^{\circ} \mathrm{C}$ & Lenangguar Village \\
\hline M.SKL K.5 & M17 & $30^{\circ} \mathrm{C}$ & Lenangguar Village \\
\hline
\end{tabular}



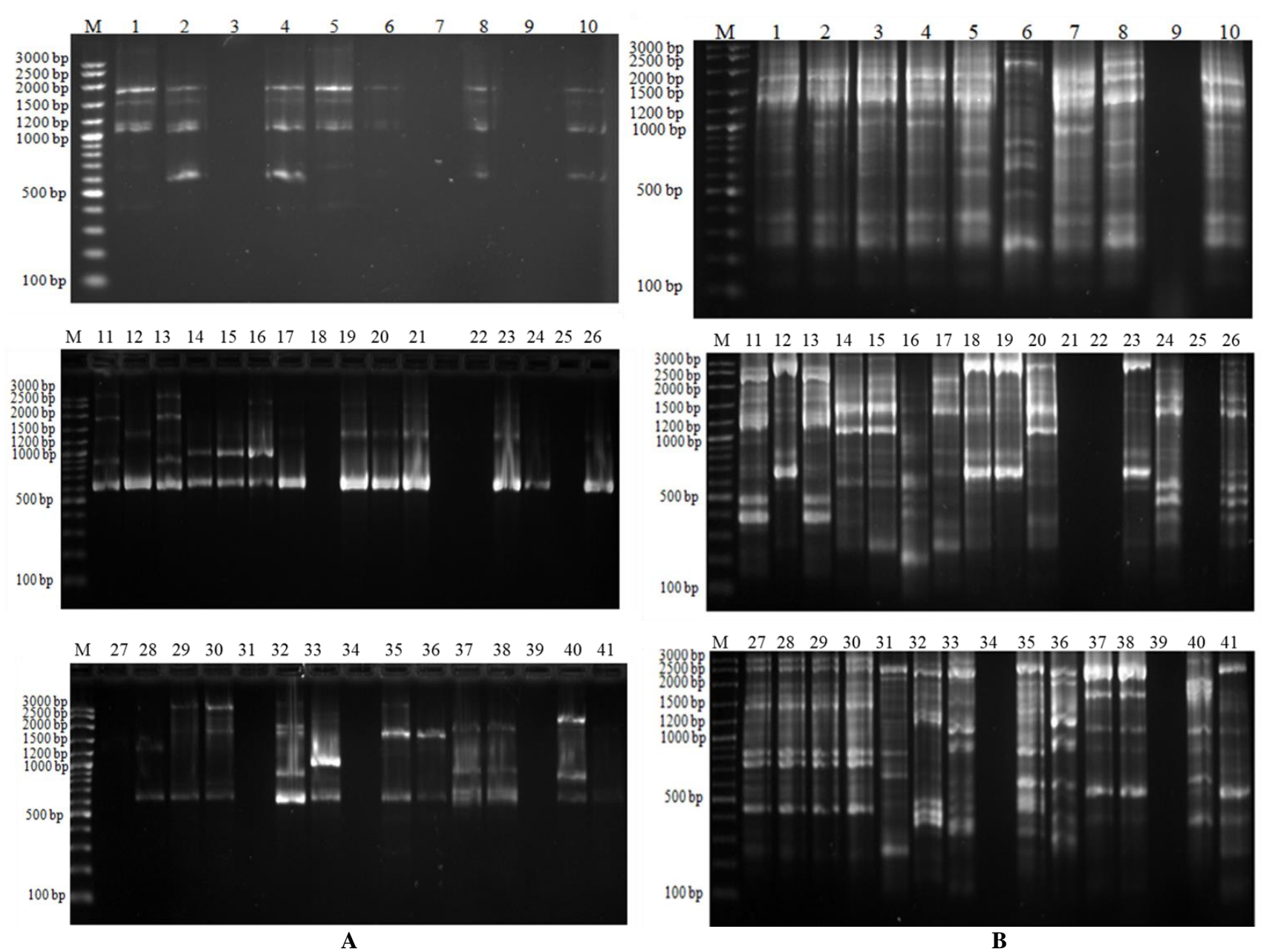

Figure 2. RAPD profiles of LAB DNA amplification using primers A. LB2 and B. GTG5 in 2\% agarose gel electrophoresis. From left to right: First lane: $1 \mathrm{~kb}$ DNA ladder, second lane up to end: LAB isolates from Sumbawa milk horse

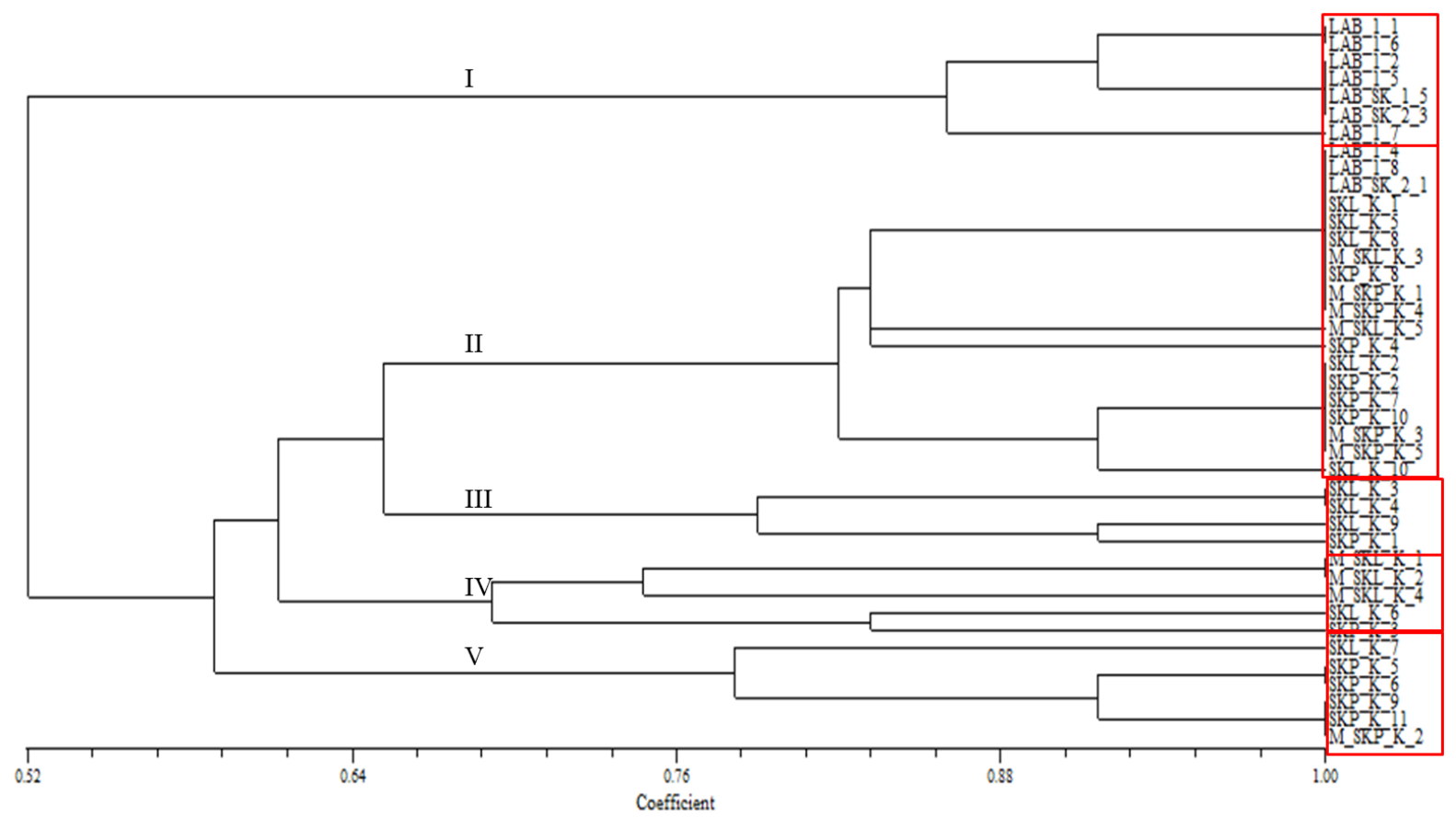

Figure 3. Dendrogram of LAB isolates from Sumbawa horse milk using LB2 primer has separated 5 clusters 


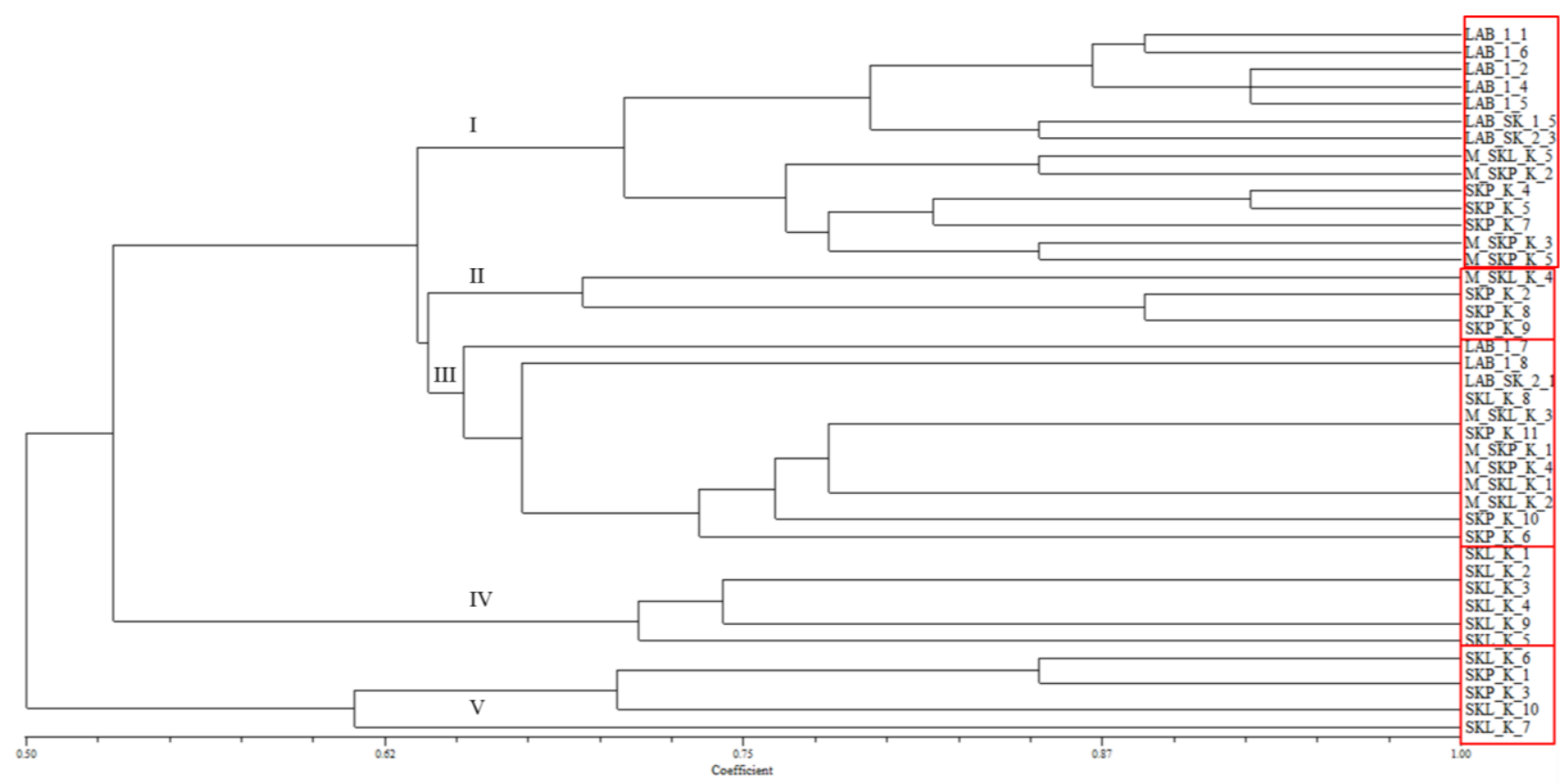

Figure 4. Dendrogram of LAB isolates from Sumbawa horse milk using GTG5 primer has separated 5 clusters

Based on the dendrogram analysis of LAB genetic diversity from Sumbawa horse milk using LB2 primers at $68 \%$ similarity, 5 clusters were found (Figure 3). The cluster I consisted of 7 LAB isolates from horse milk in the Penyaring Village. Cluster II consisted of 12 LAB isolates from horse milk in Penyaring Village and 7 LAB isolates from horse milk in Lenangguar Village. Cluster III consisted of $1 \mathrm{LAB}$ isolate from horse milk in Penyaring Village and 3 LAB isolates from horse milk in Lenangguar Village. Clusters IV consisted of 1 LAB isolate from horse milk in Penyaring Village and 4 LAB isolates from horse milk in Lenangguar Village. Clusters V consisted of 5 LAB isolates from horse milk in the Penyaring Village and 1 LAB isolate from horse milk in Lenangguar Village. This indicates that LAB isolates in clusters II, III, IV, and V obtained from horse milk in the Penyaring Village have genetic similarities with LAB obtained from horse milk in Lenangguar Village. Whereas LAB isolates from horse milk of Penyaring Village in cluster I have different genetic diversity from LAB isolates obtained from horse milk in Lenangguar Village.

Based on the dendrogram analysis of the diversity of LAB from Sumbawa horse milk using GTG5 primers at $67 \%$ similarity, 5 clusters were found(Figure 4). Cluster I consisted of $13 \mathrm{LAB}$ isolates from horse milk in the Penyaring Village and 1 LAB isolate from horse milk in Lenangguar Village. Cluster II consisted of 3 LAB isolates from horse milk of the Penyaring Village and 1 LAB isolate from horse milk in Lenangguar Village. Cluster III consisted of $8 \mathrm{LAB}$ isolates from wild horse milk in the Penyaring Village and $4 \mathrm{LAB}$ isolates from horse milk in Lenangguar Village. Cluster IV only consisted of 6 LAB isolates from horse milk in Lenangguar Village. Cluster V consisted of 2 LAB isolates from horse milk in Penyaring Village and 3 LAB isolates from horse milk in Lenangguar Village. The level of LAB genetic diversity obtained from the RAPD-PCR amplification result using GTG5 primers was more diverse (PIC 0,38). In some clusters such as cluster IV which only consisted of LAB isolates from horse milk Lenangguar Village had different genetic diversity from LAB isolates from horse milk in Penyaring Village. Cluster I, II, III, and V indicate that LAB isolates obtained from horse milk in the Penyaring Village have genetic similarities to LAB isolates obtained from horse milk in Lenangguar Village.

\section{PCR Amplification for 16S rRNA of the Lactic Acid Bacteria}

Based on the dendrogram result, the similarity percentage of GTG5 primer of LAB isolates from Sumbawa horse milk were more diverse compared to LB2 primers. Hence, the 5 clusters resulted from GTG5 primer at similarity percentage of $67 \%$ were used as representatives to determine the LAB strain for amplification of 16S rRNA (Figure 5).

\section{Sequencing and phylogenetic relationships of the lactic acid bacteria}

Based on PCR amplification result using 16S rRNA primers, a band of $1500 \mathrm{bp}$ was obtained. Then only ten LAB isolates as representative from each cluster of GTG5 primer were selected i.e.: SKP K.3, SKP K.5, SKP K.9, SK 1.5, SKL K.4, M.SKL K.1, M.SKL K.5, SKP. K4, SKP K.7, and M.SKP K.3 to proceed to a sequence (Table 3). 


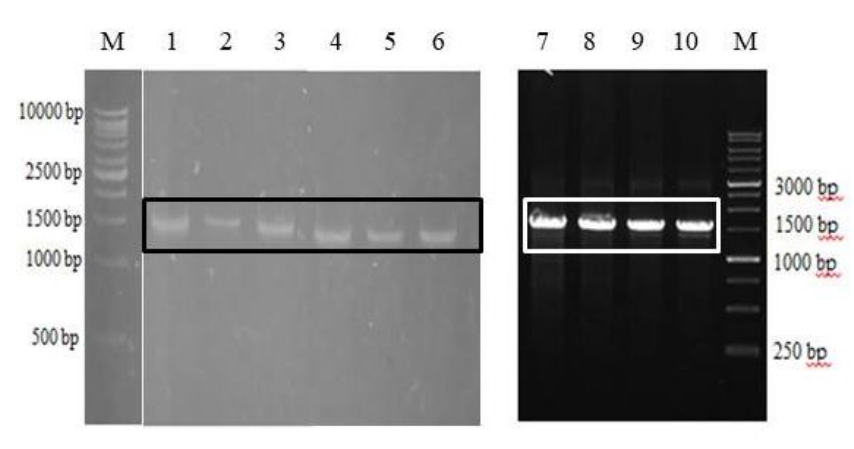

Figure 5. 16S rRNA profile of Sumbawa horse milk LAB isolates as representative from each cluster of GTG5 primer. From left to right: Lane 1: $1 \mathrm{~kb}$ marker (DNA ladder Vivantis), lane 2: SK 1.5, lane 3: SKP K.3, lane 4: SKP K.5, lane 5: SKP K.9, lane 6: SKL K.4, lane 7: M.SKL K.1, lane 8: M.SKL K.5, lane 9: M.SKP K.4, lane 10: SKP K.7, lane 11: M.SKP K.3, lane 12: 1 kb DNA ladder

Based on Table 3, seven species of LAB that were successfully identified, E. faecium sp., W. confusa sp., $L$. garvieae sp., E. thailandicus sp., L. fermentum sp., E. faecalis $\mathrm{sp}$., and $L$. petauri $\mathrm{sp}$. The phylogenetic tree of the $16 \mathrm{~S}$ rRNA sequence in Figure 6 contained sequences of LAB strains from Sumbawa horse milk (this study), sequences of several LAB from Gram-positive bacteria such as Lactobacillus plantarum, Pediococcus obtained from GenBank and sequences of some Gram-negative bacteria such as Escherichia coli, Pseudomonas aeruginosa, Chlamydia trachomatis, Helicobacter typhlonius, Legionella anisa from GenBank (Figure 6).

\section{Discussion}

The genetic diversity result from 41 single LAB colonies (Table 1) with PCR-RAPD using GTG5 primers was more diverse than the LB2 primers (Figure 2 and Table 2 ). Based on the result of DNA amplification on LAB genome (Figure 2), the GTG5 primer produced a more diverse band when compared to the LB2 primer. Analysis of LAB genetic diversity based on bands of the same size and bands of different sizes of each isolate showed the diversity of LAB (Figures 3 and 4). Based on the dendrogram analysis, the percentage of similarity of LAB isolates from Sumbawa horse milk using LB2 primers was $68 \%$ and GTG5 primers were $67 \%$. PCR amplification using the GTG5 primer was proven to be useful for the differentiation of a wide range of lactobacilli at the species, subspecies, and potentially up to the strain level (Gevers et al. 2001). Abdollahniya et al. (2018), the results of the RAPD marker from LAB traditional dairy products indicated that intra-species diversity was greater than interspecies diversity. Diversity of lactic acid bacteria isolated from fermented mare's milk products based on PCR-RFLP analysis had a total of 41 isolates that were grouped into 10 clusters. However, only three clusters were identified as LAB from Lactobacillus genus (group I with 97\%, group III with 98\%, and group VIII 75\%) (Mulyawati et al. 2019).

The identification of LAB from Sumbawa horse milk using 16 rRNA sequence was successfully identified three closely related type strains bacteria from Enterococcus sp. (M.SKP.K3), Lactococcus garvieae (SKP K.5), and Lactococcus petauri (SKP K.4) as a novel bacteria in Sumbawa horse milk compared to the previous findings reported by Mulyawati 2019, Sujaya et al. 2008 and Widiada 2006.

Based on 16S rRNA sequence obtained that M.SKP K3 isolates closely related type $E$. thailandicus which is showing $96,91 \%$ similarity. This bacteria can be a new strain type or unknown isolate. In a previous study, about the similarity of $16 \mathrm{~S}$ rRNA of the unknown isolate with reference species or strain below 97\% represented the new type strain of the unknown isolate. But, for determining an isolate as a new species certain analysis should be done along with 16S rRNA analysis, DNA hybridization, \% $\mathrm{G}+\mathrm{C}$ content, morphological, biochemical, and physiological characterization of the isolate determines the novelty of the bacterial isolate as a new species or type strain (Baltz et al. 2010; Mignard and Flandrois 2006).

Table 2. Results of polymorphic information content (PIC) LB2 and GTG5 primers in RAPD analysis

\begin{tabular}{ll}
\hline Primer & PIC \\
\hline LB2 & 0.32 \\
GTG5 & 0.38 \\
\hline
\end{tabular}

Table 3. LAB isolate Sumbawa horse milk species

\begin{tabular}{|c|c|c|c|c|}
\hline Isolate & $\begin{array}{c}\text { Finished sequences } \\
\text { totals (bp) }\end{array}$ & $\begin{array}{l}\text { Closely related type strains } \\
\text { Based on } 16 \mathrm{~S} \text { rRNA gene }\end{array}$ & $\begin{array}{c}\text { Percentage } \\
\text { similarity (\%) }\end{array}$ & Accession number \\
\hline SK 1.5 & 1397 & Enterococcus faecium & 99.86 & CP032308.1 \\
\hline SKP K.3 & 1397 & Weissella confusa & 99.39 & MK818759.1 \\
\hline SKP K.5 & 1397 & Lactococcus garvieae & 99.51 & LC376029.1 \\
\hline SKP K.9 & 1397 & Enterococcus thailandicus & 100 & AA00296 \\
\hline SKL K.4 & 1397 & Lactobacillus fermentum & 99.93 & KY249642.1 \\
\hline M.SKL K.1 & 1397 & Enterococcus faecalis & 100 & СР030045.1 \\
\hline M.SKL K.5 & 1464 & Enterococcus faecalis & 100 & CP045045.1 \\
\hline SKP K.4 & 1446 & Lactococcus petauri & 100 & CP045924.1 \\
\hline SKP K.7 & 1446 & Enterococcus thailandicus & 98.62 & LT223669.1 \\
\hline M.SKP K.3 & 1002 & Enterococcus thailandicus & 96.91 & $\mathrm{CP} 023074.1$ \\
\hline
\end{tabular}




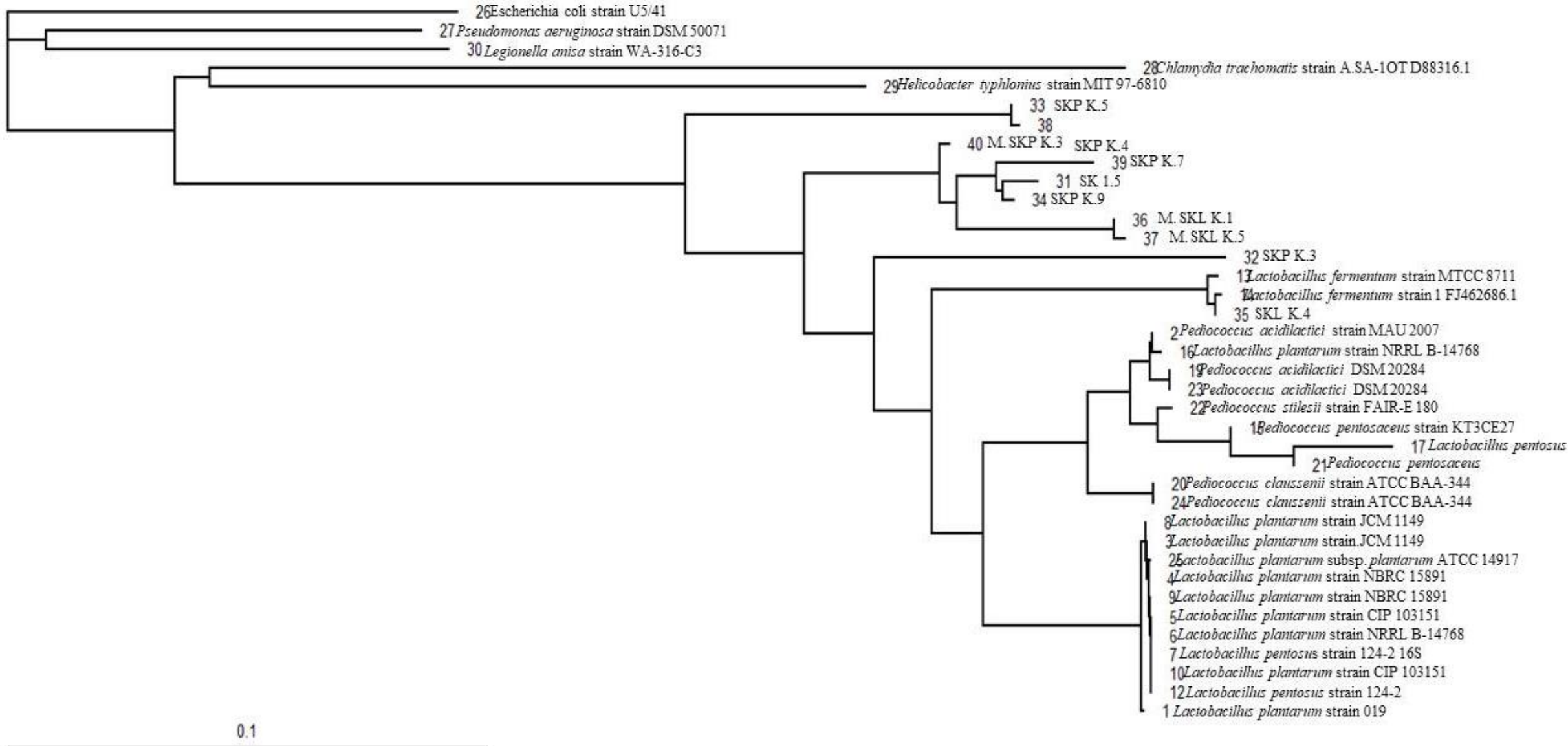

Figure 6. Phylogenetic tree based on 16S rRNA sequence analysis of LAB strains isolated from Sumbawa horse milk (this study) and several Gram-positive and Gram-negative bacteria obtained from GenBank accession. 
Isolates of SK 1.5 (E. faecium), SKP K.9, SKP K.7, M.SKP K.3 (E. thailandicus), M.SKL K.1 and M.SKL K.5 (E. faecalis) are Gram-positive lactic acid bacteria belonging to the genus Enterococcus. Enterococcus is one of the normal components of microbiota found in raw milk (Giménez-Pereira 2005). Enterococcus strains group have been isolated from raw milk are E. faecalis and $E$. casseliflavus (Gelsomino et al. 2002), E. lactis (Bauer et al. 2009), E. italicus, and E. faecium (Gaaloul et al. 2014). E. occurs in different foods of dairy products, for instance, cheeses and raw milk (Morandi et al. 2012; Elmoslih et al. 2017). Enterococcus is found in a variety of artisanal cheeses made from raw or pasteurized milk from goats, sheep, buffaloes, and cows (Cogan et al. 1997; Franz et al. 1999). The most common Enterococcus in cheese is $E$. faecalis and E. faecium (Dave et al. 1980; Centeno et al. 1995; Arizcun et al. 1997; Cogan et al. 1997; Stiles et al. 1997; Suzzi et al. 2000). From the current regulatory point of view, the genus Enterococcus is neither recommended for the QPS list nor has GRAS status. The development of highly adapted methods and legislations for Enterococcus strains are still required (Hanchi et al. 2018).

SKP K.3 isolate belongs to $W$. confusa species. This genus includes Gram-positive, catalase-negative, and nonendospore forming coccoid or rod-shaped LAB (Björkroth et al. 2014). W. confusa (Cys2-2) produces active substances (bacteriocin) with inhibitory potential. The result revealed that $W$. confusa (Cys2-2) bacteriocin exerted its bactericidal effect by weakening the membrane integrity of target cells leading to cell death (Tenea and Lara 2019).

SKP K.5 isolate belongs to $L$. garvieae species. $L$. garvieae is one of the genera of Lactococcus species (Cai et al. 2011). L. garvieae isolated from raw milk and dairy products have been reported to inhibit indicator strains due to the production of bacteriocin (Villani et al. 2001). The study of Suneel dan Basappa (2013) showed that the L.garvieae produce bacteriocin that inhibits a wide variety of pathogenic microbes which suggested to be used as an alternative type of antibiotic.

SKP K.4 isolate belongs to $L$. petauri species. This bacterium was successfully isolated from a healthy human gut (Ou et al. 2020). L. petauri has the closest relationship with $L$. garvieae and is a Gram-positive, non-motile, nonspore forming, and facultatively anaerobic (Goodman et al. 2017). L. peauri comes from the genus Lactococcus. Most members of this genus are found in fermented milk products such as cheese, yogurt, and butter (Fusco et al. 2019).

SKL K.4 isolate belongs to $L$. fermentum species. Traditional fermented dairy products including fermented yak, mare, goat, and cow milk were accurately identified as L. fermentum (42 strains) (Yu et al. 2011). Mikelsaar and Zilmer (2009), that L. fermentum strain ME-3 has the function of antimicrobial activity against intestinal pathogenic bacteria (S. typhimurium) and high antioxidant activity that it is potentially be used as a probiotic (Georgieva et al. 2015).

Based on genetic diversity result, that LAB was a predominant species founded in Sumbawa horse milk as mentioned in Table 3. Those LAB species may have great potency for probiotics or as a source for antimicrobe substance. Based on empirical evidence, it was believed that Sumbawa horse milk give benefit in term of the wellbeing of local people who consume it, yet there is no clear scientific based evident until recently. According to Hermawati (2005), such benefits of Sumbawa horse milk consumption in the local community were the ability to cure digestive-related diseases, tuberculosis, anemia, lung inflammation, and cancer.

The result demonstrates that LAB from different sources of horse milk in Sumbawa (Lenangguar Village and Penyaring Village) from RAPD analysis showed 5 clusters resulted from GTG5 and LB2 primers and based on 16S rRNA revealed a complex composition of LAB species. Such diversity of LAB provides useful information for further studies such as a selection of probiotic strain and starter culture design or antimicrobial for the industrial production of traditional fermented milk. The diversity of LAB contained in Sumbawa horse milk has the potential to be used as an antimicrobial and probiotic.

\section{ACKNOWLEDGEMENTS}

This research was funded by Ministry of Research, Technology and Higher Education (Indonesia) fiscal year 2019. All facilities were supported by Research Center for Biotechnology, Indonesian Institute of Sciences (LIPI), Bogor, West Java, and Indonesian Center for Agricultural Biotechnology and Genetic Resources Research and Development (ICABIOGRAD), Bogor, West Java. The authors would like to thank Leggina Rezy Vanggy, Liza Wati Zelayeta, and Novi Cahya Lestari (Student Department of Biotechnology, Biotechnology Faculty, Sumbawa University of Technology) for milk sampling.

\section{REFERENCES}

Abdollahniya D, Hosseini SM, Baghbaderani BK, Mordadi A, Arabestani MR. 2018. Identification of Lactobacillus species isolated from traditional dairy products using RAPD-PCR. Avicenna J Clin Microbiol Infect 5 (2): 7-13.

Arizcun C, Barcina Y, Torre P. 1997. Identification and characterization of proteolytic activity of Enterococcus spp. isolated from milk and Roncal and Idiazábal cheese. Int J Food Microbiol 38 (1): 17-24.

Baltz RH, Arnold L, Demain, Davies JE. 2010. Manual of Industrial Microbiology and Biotechnology. American Society for Microbiology, Washington DC.

Bauer R, Bekker JP, Wyk NV, du Toit C, Dicks LMT, Kossmann J. 2009. Exopolysaccharide production by lactose-hydrolyzing bacteria isolated from traditionally fermented milk. Int J Food Microbiol 131 (2-3): 260-264.

Ben Omar N, Ampe F, Raimbault M, Guyot JP, Tailliez P. 2000. Molecular diversity of lactic acid bacteria from cassava sour starch. Syst Appl Microbiol 23: 285-290.

Björkroth JA, Dicks LMTD, Endo A. 2014. The Genus Weissella. In: Lactic Acid Bacteria, Biodiversity and Taxonomy. Wiley-Blackwell, Chischester, UK

Cai, Y, Yang J, Pang H, Kitahara M. 2011. Lactococcus fujiensis sp. nov., a lactic acid bacterium isolated from vegetable matter. Intl J Syst Evol Microbiol 61: 1590-1594. 
Centeno JA, Cepeda A, Rodriquez-Otero JL. 1995. Identification and preliminary characterization of strains of enterococci and micrococci isolated from Arzúa raw cows'-milk cheese. Nahrung 39: 55-62.

Cogan TM, Barbosa M, Beuvier E, Bianchi-Salvadoris B, Cocconcelli PS, Fernandes I, Gomez J, Gomez R, Kalantzopoulos G, Ledda A, Medina M, Rea MC, Rodriguez E. 1997. Characterization of the lactic acid bacteria in artisanal dairy products. J Dairy Res 64: 409-421.

Chao SH,Tomii Y,Watanabe K, Tsai YC. 2008. Diversity of lactic acid bacteria in fermented brines used to make stinky tofu. Intl J Food Microbiol 123: 134-141

Chao SH, Huang HY, Kang YH, Watanabe K, Tsai YC. 2012. The diversity of lactic acid bacteria in a traditional Taiwanese millet alcoholic beverage during fermentation. LWT-Food Sci Technol 51: $135-142$

Dave JM, Desai MV, Upadhayay KG, Thakar PN. 1980. Incidence of Enterococci in buffalo milk Cheddar cheese. GAU Res J 5: 44-47.

Delavenne EJ, Mounier F, Déniel G. Barbier, G. Le Blay. 2012. Biodiversity of antifungal lactic acid bacteria isolated from raw milk samples from cow, ewe and goat over one-year period. Intl J Food Microbiol 155: 185-190

Elmoslih A, Zanzan M, Aissa R. 2017. Isolation and characterization of bacteriocinogenic Enterococcal and Lactococcal strains from south of Morocco dairy product. Biotechnol J Intl 18 (4): 1-16.

Franz CMAP, Van Belkum MJ, Holzapfel WH, Abriouel H, Gálvez A. 2007. Diversity of Enterococcal bacteriocins and their grouping in a new classification scheme. FEMS Microbiol Rev 31 (3): 293-310.

Fusco V, Quero GM, Poltronieri P, Morea M, Baruzzi F. 2019 Autochthonous and probiotic lactic acid bacteria employed for production of "advanced traditional cheeses". Foods 8 (9): 412.

Gaaloul N, Ben Braiek O, Berjeaud JM. 2014. Evaluation of antimicrobial activity and safety aspect of Enterococcus italicus GGN10 strain isolated from Tunisian bovine raw milk. J Food Safety 34 (4): 300311.

Gelsomino R, Vancanneyt M, Cogan TM, Condon S, Swings J. 2002. Source of Enterococci in a farmhouse raw-milk cheese. Appl Environ Microbiol 68 (7): 3560-3565.

Georgieva R, Yocheva L, Tserovska L, Zhelezova G, Stefanova N, Atanasova A, Danguleva A, Ivanova G, Karapetkov N, Rumyan N, Karaivanova E. 2015. Antimicrobial activity and antibiotic susceptibility of Lactobacillus and Bifidobacterium spp. intended for use as starter and probiotic cultures. Biotechnol Biotechnol Equip 29 (1): 84-91.

Gevers D, Huys G, Swings J. 2001. Applicability of rep-PCR fingerprinting for identification of Lactobacillus species. FEMS Microbiol Lett 205: 31-36

Giménez-Pereira ML. 2005. Enterococci in Milk Products. [Dissertation] Massey University Palmerston North, New Zealand.

Goodman LB, Lawton MR, Franklin-Guild RJ, Anderson RR, Schaan L, Thachil AJ. 2017. Lactococcus petauri sp. nov., isolated from an abscess of a sugar glider. Intl J Syst Evol Microbiol 67 (11): 4397 4404.

Hakim NS, Suada IK, Sampurna IP. 2013. Ketahanan susu kuda Sumbawa pada penyimpanan suhu ruang ditinjau dari total asam, uji didih dan warna. J Veteriner 2 (4): 369-374. [Indonesian]

Hanchi H, Mottawae W, Sebei K, Hammami R. 2018. The genus Enterococcus: between probiotic potential and safety concerns-an update. Front Microbiol 9: 1791.

Hermawati D, Sudarwanto, M, Soekarto ST, Zakaria FR, Sudardjat S, Tjatur Rasa FS. 2004. Aktivitas antimikroba pada susu kuda Sumbawa. Jurnal Teknol dan Industri Pangan 15 (1): 47-53. [Indonesian]

Hermawati D. 2005. Kajian Aktivitas dan Karakterisasi Senyawa Antimikroba dari Susu Kuda Sumbawa. [Dissertation]. Pascasarjana Institut Pertanian Bogor, Bogor. [Indonesian]

Manguntungi B, Perkasa AS, Yulianti, Kusdianawati, Hastuti HP. 2018. Isolasi bakteri asam laktat dari susu kuda liar Sumbawa dan potensi antibakteri pada susu kuda liar Sumbawa. Biota 3 (2): 62-69. [Indonesian]
Mikelsaar M, Zilmer M. 2009. Lactobacillus fermentum ME-3 an antimicrobial and antioxidative probiotic. Microb Ecol Health Dis 21 (1): 1-27.

Mignard S, Flandrois JP. 2006. 16S rRNA sequencing in routine bacterial identification: a 30-month experiment. J Microbiol Methods 67 (3): 574-581.

Mulyawati AI, Jatmiko YD, Mustafa I, Ardyati T, Suharjono. 2019. Diversity of lactic acid bacteria isolated from fermented mare's milk products. IOP Conf Ser: Earth Environ Sci 230: 012104. DOI: 10.1088/1755-1315/230/1/012104

Mustopa AZ, Fatimah. 2014. Diversity of lactic acid bacteria isolated from Indonesian traditional fermented foods. Microbiology 8 (2): 48 57.

Mustopa AZ. 2013. Isolation and Characterization of Lactobacillus plantarum S34 from Indonesia Traditional Food. [Dissertation]. Dan Kook University, Korea.

Morandi S, Silvetti T, Brasca M. 2013. Biotechnological and safety characterization of Enterococcus lactis, a recently described species of dairy origin. Anton Leeuw Intl J G 103 (1): 239-249.

Ou YJ, Ren QQ, Fang ST, Wu JG, Jiang YX, Chen YR, Zhong Y, Wang DD, Zhang GX. 2020. Complete genome insights into Lactococcus petauri CF11 isolated from a healthy human gut using second-and third-generation sequencing. Front Genet 11: 119. DOI: 10.3389/fgene.2020.00119.

Roldán-Ruiz I, Calsyn E, Gilliland TJ, Coll R, van Eijk MJT, De Loose M. 2000. Estimating genetic conformity between related ryegrass (Lolium) varieties. 2. AFLP characterization. Mol Breed 6: 593-602.

Shi T, Nishiyama K, Nakamata K, Aryantini N P D, Mikumo D, Oda Y 2012 Isolation of Potential Probiotic Lactobacillus rhamnosus Strains from Traditional Fermented Mare Milk Produced in Sumbawa Island of Indonesia. Biosci Biotechnol Biochem 76 (10): 1897-903.

Soengas P, Velasco P, Padilla G, Ordás A, Cartea ME. 2006. Genetic relationships among Brassica napus crops based on SSR Markers. Hort Sci 41: 1195-1199.

Stiles ME, Holzapfel WH. 1997. Lactic acid bacteria of foods and their current taxonomy. Intl J Food Microbiol 36 (1): 1-29.

Sujaya N, Ramona Y, Widarini NP, Suariani NP, Dwipayanti NMU, Nocianitri KA, Nursini NW. 2008. Isolasi dan karakterisasi bakteri asam laktat dari susu kuda Sumbawa. J Veteriner 9 (2): 52-59. [Indonesian]

Suneel D, Basappa K. 2013. Identification and characterization of Lactococcus garvieae and antimicrobial activity of its bacteriocin isolated from cow's milk. Asian J Pharm Clin Res 6: 104-108.

Suzzi G, Caruso M, Gardini F, Lombardi A, Vannini L, Guerzoni ME, Andrighetto C, Lanorte MT. 2000. a survey of the enterococci isolated from an artisanal Italian goat's cheese (semicotto caprino). J Appl Microbiol 89 (2): 267-274.

Tenea GN, Lara MI. 2019. Antimicrobial compounds produced by Weissella confusa Cys2-2 strain inhibit Gram-negative bacteria growth. CYTA-J Food 17 (1): 105-111.

Villani F, Aponte M, Blaiotta G, Mauriello G, Pepe O, Moschetti G. 2001. Detection and characterization of a bacteriocin, garviecin L1-5, produced by Lactococcus garvieae isolated from raw cow's milk. J Appl Microbiol 90 (3): 430-439.

Welsh J, McClelland M. 1990. Fingerprinting genomes using PCR with arbitrary primers. Nucleic Acids Res 18 (24): 7213-7218.

Widiada IGN, Antara NS, Aryanta WR. 2006. Identification and growth succession of lactic acid bacteria in wild horse milk of Bima during storage. In: Annual Scientific Meeting of PERMI-2006. Udayana University, Bali. [Indonesian]

Williams JG, Kubelik AR, Livak KJ, Rafalski JA, Tingey SV. 1990. DNA polymorphisms amplified by arbitrary primers are useful as genetic markers. Nucleic Acids Res 18 (22): 6531-655.

Yu J, Wang WH, Menghe BL, Jiri MT, Wang HM, Liu WJ, Bao QH, Lu Q, Zhang JC, Wang F, Xu HY, Sun TS, Zhang HP. 2011. Diversity of lactic acid bacteria associated with traditional fermented dairy products in Mongolia. Intl J Dairy Sci 94 (7): 3229-3241.

Zacharof MP, Lovitt RW. 2012. Bacteriocins produced by lactic acid bacteria. APCBEE Procedia 2: 50-56. 